Published on Reviews in History (https://reviews.history.ac.uk)

\title{
Stormy Present: Conservatism and the Problem of Slavery in Northern Politics, 1846-1865
}

Review Number: 2260

Publish date: Thursday, 28 June, 2018

Author: Adam I. P. Smith

ISBN: 978-1469633893

Date of Publication: 2017

Price: $£ 33.71$

Pages: 352pp.

Publisher: The University of North Carolina Press

Publisher url: https://www.uncpress.org/book/9781469633893/the-stormy-present/

Place of Publication: Chapel Hill

Reviewer: Michael Green

Historians have been fighting about the causes and effects of the Civil War since they were using quill pens, and they figure to keep doing so until long after the laptop computer on which this is written has become an antique. Now Adam I. P. Smith, a scholar of mid-19th-century America and especially its political culture, has joined the battle to argue that one of the dominant impulses and attitudes associated with the years leading up and including the American Civil War was conservatism. As the conflicting interpretations of the era suggest, that may be the case, but the reforms and reformers before the war and the important ways in which the war changed the United States make the argument seem debatable on its face. Nonetheless, his argument that a conservative polity enacted significant reform reflects the contradictions of Americans and their history. Although he clearly reflects the influence of earlier generations of scholars (who he mercifully engages with more in the footnotes than in the text), Smith also offers a smart and different interpretation of the era that gives those who study the period, and American history more broadly, a great deal to think and argue about.

Are Americans liberal or conservative? The question may have gained added resonance in recent years (and collide with similar questions about Europe), but the answer is simple: yes. The terms also present problems because labels like conservative and liberal have different meanings at different times. They can easily be applied to the same individual. Richard Hofstadter, who said so many things well, wrote of Lincoln, 'Although he helped to form a new party, uprooted slavery and the aristocracy of the South, led a revolutionary change in the structure of national power, and paved the way for the success of industrial capitalism, he did all these things with the intent of restoring the Union as it had been, saving the common man's control of the government, and protecting the existing rights of free labor'.(1)

Hofstadter may have understated the case. Generations of historians have argued that the Civil War and Reconstruction constituted a Second American Revolution. The leaders and events of the era coupled the meaning of the Declaration of Independence to the Constitution in different ways than they had ever been connected before, and led to the Thirteenth, Fourteenth, and Fifteenth Amendments, which deeply affected that document's meaning. These changes also followed - or culminated - an era of American history that scholars have described as the 'age of reform', which included abolitionism, women's rights, utopian 
socialism, and a host of other movements. When the federal government ceased to protect black voters in the South after the 1876 election, that retrenchment also signaled a period of conservatism in which the federal government supported business at the expense of laborers, whether native-born or immigrant, black or white, and farmers in the South and West chafed at the primacy of market capitalism and the federal government's indifference to their plight.

Those events came long after the period covered in Smith's book, whose title, The Stormy Present, refers to the first Republican president, Abraham Lincoln, whose 1862 message to Congress warned of the need to dismiss 'the dogmas of the quiet past' as 'inadequate to the stormy present'. That past was hardly quiet, as Lincoln knew and we know, yet, as Smith notes, 'This was an era in US history in which self-described conservatives dominated public life .... Even those who sought radical changes in American society often felt the need to argue that they embodied true conservatism while their opponents traded in false or pretended conservatism. Calling something conservative was a way of legitimizing it: whether opposition to the Fugitive Slave Act or mob violence, whether support for war or for peace' (p. 3). In making this argument, Smith tackles two issues: that studies of the Civil War era have tended to focus on radicals on both sides, and that conservatism was, unlike abolitionism or women's rights, not a movement. Rather, he said, conservatism 'is better understood as a disposition, a way of signaling a measured, mature approach to the problems of the world', and therefore it can be harder to grasp or nail down (p. 5).

Smith approaches the Civil War era in a refreshingly different way. His jumping-off point, to which he occasionally returns, is the Astor Place Riot in New York City in 1849, when a controversy over a British actor culminated in militiamen killing 25 protesters. It seemed to involve just a theatrical performance and a disagreement that got out of hand, but Smith shows that the performance and the response also reflected American perceptions of their nationality, their role in the world, and what he considers their innate conservatism; as Smith notes, it grew out of a feud between two actors with results that 'raised in an especially troubling form some constitutional questions about majoritarianism (should the majority rule even if it meant preventing an actor who was the minority's favorite from performing?), about political legitimacy (did the state, in a republic, have the right to use force, even to protect property and order?), and about citizenship (what special obligations did living in a republic impose on citizens and government alike?). As Northerners struggled with the problem of slavery, they ran, again and again, into exactly these fundamental issues ...' (pp. 25-6). Smith's analyses of the connections that American conservatives made to English and European figures and events - Oliver Cromwell and the Puritan Revolution, and the Italian revolt against Austria-Hungary, for example - benefit from the perspective gained from being based outside the United States. His descriptions of Stephen Douglas as having 'his waistcoats ever more tightly stretched as his expanding girth raced to keep up with his territorial ambition for the Union' (p. 69), and Nativist Joel Headley as 'a beak-faced scribbler of rather superficial history books (one critic rightly called them "flatulent and swooshy")' deserve to be quoted frequently and joyfully $(69,83)$.

Smith's analysis combines political and intellectual history to conclude that, for northerners, 'their guiding star, it often seemed, was a conviction that their choices were "conservative", and that "self-described conservatives dominated public life ... Even those who sought radical changes in American society often felt the need to argue that they embodied true conservatism while their opponents traded in false or pretended conservatism' (3). To oppose the spread of slavery, or even demand its elimination, might have seemed radical to many Americans at the time, and those of us looking back on these events today. But the effort to expand the peculiar institution and its footprint contributed to 'the destabilization of society' and the breaking of covenants, which religious publications emphasized and others found to be a logical, conservative argument (p. 78). One such covenant concerned the federal government's role in protecting slavery, which increased exponentially with the passage of the Fugitive Slave Act as part of the Compromise of 1850. Smith points to Anthony Burns's forced return from freedom in Massachusetts to slavery in Virginia. Most studies describe the response of Bostonians to it as moving them toward abolitionism, which certainly would be considered radical. To Smith, though, it also was a turning point for conservatives 'because it dramatized the shocking underlying reality of the act -the massive use of federal force to capture and subdue a man who had committed no crime under Massachusetts law ... In the face of what seemed to 
be such an egregious insult to the due process of law in a free state, the antislavery case now seemed entirely defensive and eminently conservative', protecting the status quo (pp. 47-8).

Another, stronger covenant was the Missouri Compromise, and the Kansas-Nebraska Act 'pushed selfdescribed Whiggish conservatives to use a language of confrontation they would previously have avoided, willingly embracing the term "Slave Power", for example, that was first introduced into American politics in the 1840s by Northern Democrats - who, in their own right, had claimed to be conservatives dedicated to keeping the Union as it was with a minimum of conflict' (p. 79). Thus, it became possible to argue - and Smith makes the case -that the most radical candidate for president in 1860 (and radical does not, in this case, refer to the most strongly anti-slavery members of the Republican Party) was none other than John Breckinridge. 'Douglas Democrats, like Republicans -and, for that matter, Northern Constitutional Unionists - simply could not accept the radical moral, political, or constitutional implications of a federal slave code', Smith writes. 'The Breckinridge campaign's role in the North was essentially to be the foil against which the other campaigns would compete to offer the most plausible, safe, conservative alternative' (pp. 154-5).

Smith posits a different approach to judging the key events of the Civil War era. When Lincoln's inaugural address talked about secession as anarchy and his duty to uphold the Constitution, he both took a conservative position and subtly suggested that the Confederates were the opposite of the conservative defenders of the founding fathers' government that they purported to be. When Lincoln issued the Emancipation Proclamation, he certainly engaged in a radical and revolutionary act, but it also was conservative: an effort to save the existing Union, but in a different form.

In a few places, Smith might have benefited from using additional sources or arguments. In 1858, while their debates certainly provide evidence of Lincoln claiming to take the more conservative approach, one of the factors that helped Douglas stave off Lincoln was the support he received from former Whigs Horace Greeley and John J. Crittenden. Welcoming the break between Douglas and James Buchanan over the Lecompton Constitution and what Douglas saw as the abuse of popular sovereignty, the New York Tribune editor adopted the policy that the enemy of his enemy was his friend. When Greeley saw an alliance with Douglas as a possibility, Lincoln was upset enough to complain about it and for his law partner, William Herndon, to meet with the mercurial Greeley. Crittenden, who pops up a few times in Smith's work, endorsed Douglas as truer to Henry Clay's spirit of compromise than Lincoln, who had considered Clay his 'beau ideal of a statesman'. It might have been worthwhile for Smith to examine these opinions and maneuvers.

Other figures could have given Smith additional support for his argument. He is unclear about when Senators James Doolittle and Lyman Trumbull returned to the Democratic Party; considering that a biographer of Trumbull called him a 'conservative radical', some deeper investigation might have been warranted. Francis Preston Blair, Sr., appears twice in the book, but neither of his sons does. Frank Blair served in Congress and as a general, and his allies in Missouri were part of a battle between Republican radicals and conservatives for power. As postmaster general, Montgomery Blair took publicly conservative stands that caused Lincoln some pain with radicals, but Lincoln stood by him. In 1864, Blair and Samuel L.M. Barlow, a New York Democratic leader who helped fund Manton Marble's New York World, corresponded about the possibility of Democrats backing the Thirteenth Amendment. Barlow ultimately demurred, but this exchange, and other arguments in Michael Vorenberg's Final Freedom, could have provided some additional underpinning to Smith's case for the political power of conservatism in this period.

These works and arguments might have improved Smith's case, but a larger question remains: does his interpretation hold up? Were northerners as conservative as he contends, and was their conservatism as important as he thinks? To suggest the dominance or predominance of such conservatism in the North may go a bit too far, not only because it can diminish the changes the Civil War era wrought, but also because it can make the politics and leading politicians of the time more unified than they were. Consider his quotation of Henry Raymond's New York Times saying of popular sovereignty, 'The great mass of the people in all 
sections, whatever may be their opinions upon its legal validity, recognize it as a fair, just and safe way of solving a very difficult problem ... which satisfies the instinct of nine-tenths of the American people' ( $\mathrm{p}$. 126). Perhaps The Times meant northern people, because southerners certainly disagreed. The Times also said, in the same editorial, 'Douglas will actually represent in the South that hostility to Slavery extension which is already the unanimous sentiment of the North. He will contest upon slave soil the power of the Federal Government to extend Slavery: and while his position on this question is, in our judgment, unsound and untenable, it is probably the only ground upon which any contest whatever could be maintained in the Southern States'. The Times also referred to the Republican Party as the embodiment of 'the democratic conservatism of the country' (The New York Times, June 26, 1860, p. 4). The latter may well have been true, but given The Times's description of Douglas's position as 'unsound and untenable', the reader is left to wonder how much of this was electioneering in pursuit of Democratic votes, and how much of it was what Raymond actually believed. Given that Raymond drafted the original Republican 'Address to the People' in 1856 that called for 'resistance by constitutional means of slavery in any territory', he seems to have looked more askance at popular sovereignty than suggested here.

Nor were the northern party standard-bearers in 1860, Lincoln and Douglas, quite so close as they appear here. Abolitionists were too radical for the taste of many Americans, and it behooved Republicans to maintain a distance. But both the abolitionists who demanded an immediate end to slavery and the Republicans who saw it happening belonged to what Charles Sumner, who fell into both groups, called 'the anti-slavery enterprise'. Minimizing the differences between them and those outside of their political orbit requires caution (and that is not to say that Smith lacked caution in his approach). One of the most glorious, incorrect quotations of the era - if indeed it was even said - came when William Henry Seward, tired of an outburst from Douglas on the Senate floor, replied, 'Douglas, no man will ever be President of the United States who spells negro with two g's', and Douglas himself had claimed not to care whether slavery was voted up or down. Where Douglas stood was a far cry from where the moderate Lincoln and, indeed, most conservative Republicans stood.

That does not make Republicans of the Civil War era a radical or even un-conservative party. Ultimately, as Lincoln made clear in his debates with Douglas, the Cooper Union speech, and the Gettysburg Address, and as Hofstadter suggests, he and his party stood for what the Founding Fathers believed. Democrats and other political groups made the same argument, for a variety of understandable reasons: not only because so many Americans claimed to revere them, as they continue to do, but also because some voters alive in the 20 years on which Smith focuses actually knew them. Further, as Smith argues, voters individually had to come to grips with changing times, and it is hardly controversial to suggest that they preferred that those changes come slowly, if at all.

Similarly, Smith is trying to change how we view the Civil War era. If he succeeds, the change will come slowly, and many historians will prefer a different interpretation to which they already are wedded. In other words, they might prefer the status quo, which would seem to be conservative, instead of the significant change that Smith's argument embodies - and could therefore be considered radical. That brings us back to the question of what descriptions like 'conservative' mean, if anything. But, agree with him or not, Smith has given us a well-written, well-argued, and welcome book. Those who study the 19th century, or American politics, or both, can agree or disagree, but they certainly should reckon with it. Perhaps, as the Hofstadter quotation suggests, they already have, but Smith has made us reconsider it with fresh eyes and eloquence.

\section{Notes}

1. Richard Hofstadter, The American Political Tradition And the Men Who Made It (New York, NY, 1948), p. vi.Back to (1) 


\section{Other reviews:}

\section{Jacobin}

https://www.jacobinmag.com/2017/12/civil-war-abraham-lincoln-slavery-stormy-present-review [2]

Source URL:https://reviews.history.ac.uk/review/2260

\section{Links}

[1] https://reviews.history.ac.uk/item/296332 [2] https://www.jacobinmag.com/2017/12/civil-war-abrahamlincoln-slavery-stormy-present-review 